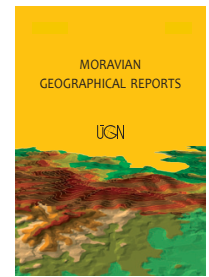

MORAVIAN GEOGRAPHICAL REPORTS

\title{
Changing European retail landscapes: New trends and challenges
}

\author{
Josef KUNC ${ }^{\text {a }}$, František KRIŽAN ${ }^{\text {b }}$
}

\begin{abstract}
During the second half of the $20^{\text {th }}$ century, consumption patterns in the developed market economies have stabilised, while in the transition/EU-accession countries these patterns were accepted with unusual speed and dynamics. Differences, changes and current trends in Western Europe and post-socialist countries in the quantity and concentration of retailing activities have been minimised, whereas some distinctions in the quality of retail environments have remained. Changes have occurred in buying habits, shopping behaviour and consumer preferences basically for all population groups across the generations. This article is a theoretical and conceptual introduction to a Special Issue of the Moravian Geographical Reports (Volume 26, No. 3) on "The contemporary retail environment: shopping behaviour, consumers" preferences, retailing and geomarketing". The basic features which have occurred in European retailing environments are presented, together with a comparison (and confrontation) between Western and Eastern Europe. The multidisciplinary nature of retailing opens the discussion not only from a geographical perspective but also from the point of view of other social science disciplines that naturally interconnect in the retail environments.
\end{abstract}

Keywords: retail landscapes, retailing, shopping behaviour, consumer preferences, resilience, Western Europe, Eastern Europe

Article history: Received 5 March 2017, Accepted 13 September 2018, Published 30 September 2018

\section{Introduction}

Since the post-war era of the 1950 s, the retail sector in Western Europe experienced a similar revolution to the industrial sector one hundred years earlier. The phenomenon of the 'industrialisation of retail' was thus replicated in the form of the internationalisation tendencies of multinational corporations and chains, resulting in the giant concerns such as the American Wal-Mart, French Carrefour, German Metro, Dutch Ahold and even Swedish IKEA. Despite all of these tendencies, the retail sector has never became as globalised as industry, which can be attributed to specific consumer cultural habits (Cliquet, 2006).

The top ten retail companies according to sales in the fiscal year 2016 are presented in Table 1. The dominant chains are still the ones with origins in the USA (with an unbeatable Wal-Mart and Internet Amazon with the highest year-on-year growth), with only three European companies that specialise in food and fast-moving goods.

Retailing and its activities, together with services, are in the long term the most significant vehicles for change, new trends and innovations in the tertiary sector. At the same time, however, in its breadth the retail sector is one of the most distinctive parts of worldwide globalisation and internationalisation trends of recent decades, and also one of the most visible features of the economic transformations in post-socialist and developing countries, where the dynamics of change have been extraordinary and relatively unique (Nagy, 2001; Burt, 2006; Szczyrba, 2005; Machek, 2012). The new dimension of large-format chain stores and shopping centres gradually overshadowed the traditional forms of retail. The shopping centres, in particular, became a phenomenon with both commercial and non-commercial purposes, and substituted as a function of public space to some extent (Crosby et al., 2005; Coleman, 2012; Pospěch, 2015).

\section{Changes, differences and trends in European retail landscapes}

The structure of the retail sector has been transformed considerably across Europe in recent decades. During the second half of the twentieth century, consumption patterns in the developed market economies stabilised, while in

\footnotetext{
a Department of Regional Economics and Administration, Faculty of Economics and Administration, Masaryk University, Brno, Czech Republic (*corresponding author: J. Kunc, e-mail: kunc@econ.muni.cz)

${ }^{b}$ Department of Regional Geography, Protection and Planning of the Landscape, Faculty of Natural Sciences, Comenius university in Bratislava, Slovakia
} 


\begin{tabular}{lccc}
\hline Name (country) & $\begin{array}{c}\text { Retail income } \\
\text { (billion USD) }\end{array}$ & $\begin{array}{c}\text { The year-on-year } \\
\text { difference (\%) }\end{array}$ & $\begin{array}{c}\text { Number of countries } \\
\text { in which they operate }\end{array}$ \\
\hline Wal-Mart Stores (USA) & 485.9 & 0.8 & 29 \\
Costco Whole Sale Corp. (USA) & 118.7 & 2.2 & 10 \\
The Kroger (USA) & 115.3 & 5.0 & 1 \\
Schwarz Group (GERMANY) & 99.3 & 5.3 & 27 \\
Walgreens Boots Aliance (USA) & 97.1 & 8.3 & 10 \\
Amazon (USA) & 94.7 & 19.4 & 14 \\
The Home Depot (USA) & 94.6 & 6.9 & 4 \\
Aldi Group (GERMANY) & 84.9 & 4.8 & 17 \\
Carrefour (FRANCE) & 84.1 & -0.4 & 34 \\
CVS Health Corp. (USA) & 81.1 & 12.6 & 3 \\
\hline
\end{tabular}

Tab. 1: The top 10 retail companies in the world according to sales in the fiscal year 2016 (Note: We may mention some other important European retail corporations such as Tesco (UK, $11^{\text {th }}$ place, income of 72.4 billion USD), Ahold Delhaize (Netherlands, $14^{\text {th }}, 69.06$.), Auchan Holding (France, $18^{\text {th }}, 57.2 b$.), the Rewe Group (Germany, 22 $2^{\text {nd }}, 44.6 b$.) or IKEA (Sweden, $27^{\text {th }}$, 38.0b.)

Source: RetailNews (3/2018)

the 1990s in the transition countries these patterns had been accepted, and with unusual speed and dynamics (Kok, 2007; Kunc et al., 2013; Križan et al., 2014). Rapid adaptation of Western norms by the Eastern ${ }^{1}$ markets was supported by the entry and dominance of Western capital. The potential of the Eastern markets, insufficient domestic competition, benevolent legislation as well as large (latent) consumer appetites attracted Western retailers who were facing a slowdown in the growth of their own markets during the 1990s and even later (Myers, Alexander, 1997; Burt, 2006).

In the middle of the $1990 \mathrm{~s}$, for example, all V4 countries (the Czech Republic, Hungary, Poland and Slovakia) were listed in the 30 countries with the best expanding retail markets in the world (Kearny, 1995). At the same time, international competition was rather extensive as many large-scale retail concerns decided to 'control' the Eastern markets simultaneously, and not all of them have lasted to the present (Szczyrba, 2010). Internationalisation became the dominant feature of European retailing (Burt, 2010). The process of internationalisation, which started first in Central and then in Eastern European countries, was thus very fast. The differences among European countries were virtually removed as far as quantity and concentration are concerned, yet certain contrasts remained regarding the quality of the products and the culture of the retail environment.

Although Europe has had to face great challenges in the last few years that posed threats to its stability (such as issues with refugees and terrorism, political tensions between Russia and Turkey, the Brexit referendum in the UK, etc.), the European economy and private consumption appeared to be very strong, which has also been acknowledged as due to the trust of consumers (Johnson, 2017). Despite the yearon-year growth in the retail trades in 2016 (by 1.7\%), in almost all countries of the EU-28 stationary retail declined. The growth was thus maintained predominantly by on-line trading (e-commerce), whose significance keeps increasing in Europe even though the dynamics compared to previous years have slowed in the developed markets (e.g. Germany and Austria). In the Czech Republic, for example, in 2017, on-line sales have reached a share of $10.5 \%$ of the entire retail turnover (Geomarketing, GfK, 2017).

In 2016 , the market value of the retail sector in Western Europe was approximately 2.6 trillion Euros, which was the highest amount in the last five years despite the above-mentioned declines. Compared to Eastern Europe the difference is obvious. There was also a year-on-year growth of the market value of retailing in the East, yet the numbers in 2016 were merely 565.6 billion Euros. In Western Europe, there are still many economically strong countries such as France and Germany, and compared to the Eastern countries they are unrivalled. The market value of retailing only in Germany represents one-fifth of the entire retail sector in Western Europe, and together with France, retailing represents almost one half of all of Western Europe (Geomarketing, GfK, 2017; RetailNews 1-2/2018).

The decrease in stationary retailing results in a decrease in the selling areas in European countries, predominantly in the developed markets. An increase in selling areas in food retail is often compensated for by the decrease in other segments of retailing (RegioData Research, 2017). In general, the selling areas in the stationary markets are in decline, which is, inter alia, a result of Internet (e-commerce) competition and due to the increasingly common use of so-called smart technologies (Pantano, 2017; Priporas et al., 2017). The retail companies in Western Europe are nowadays facing challenges that were unknown in the past - regarding the decreased turnover, profits and a strong pressure on prices. The decrease in selling areas naturally results in a stronger concentration of retail outlets, and at present, it happens very often that only three or four of the largest retail chains control up to $90 \%$ of the market of a given country (Geomarketing, GfK, 2017). Despite the above-mentioned facts and further expected declines, the selling area per person remains higher in the most developed markets within the EU, compared to more recent accession countries (see Tab. 2).

\footnotetext{
${ }^{1}$ Western' and 'Eastern' in this paper refer largely to the more developed Western European countries, original members of the EU, compared to the Eastern (Central) European countries, with accession to the EU starting in 2004 and sometimes characterized as 'transition' economies.
} 


\begin{tabular}{lclc}
\hline Country & $\begin{array}{c}\text { Retail area } \\
\left(\mathbf{m}^{2}\right)\end{array}$ & Country & $\begin{array}{c}\text { Retail area } \\
\left(\mathbf{m}^{\mathbf{2}}\right)\end{array}$ \\
\hline Austria & 1.67 & Czech Republic & 1.04 \\
Belgium & 1.64 & Italy & 1.03 \\
Netherlands & 1.61 & Hungary & 1.02 \\
Switzerland & 1.47 & Slovakia & 1.01 \\
Germany & 1.44 & Poland & 0.95 \\
Sweden & 1.27 & Greece & 0.74 \\
France & 1.23 & Bulgaria & 0.74 \\
Spain & 1.12 & Romania & 0.70 \\
Croatia & 1.10 & Ukraine & 0.44 \\
Great Britain & 1.09 & & \\
\hline
\end{tabular}

Tab. 2: Retail selling area per person in 2016 in selected

European countries (in sq. $m$ )

Source: RegioData Research (2017)

After the stage of internationalisation and the adoption of Western models and patterns (of buying behaviour), the Eastern markets reached a stage of consolidation with a relative stabilisation of the market (Coe and Hess, 2005). Reactions to the recent (2008) economic recession were similar to those in Western countries: the selling areas rather stagnated; and the concentration and saturation of the retail environment were also already very high (Simová, 2010). In the terms of some of the parameters used in these studies (e.g. regarding large-scale concepts, specifically the number of hypermarkets per person), the transitional Czech Republic is among the leading countries in Europe (Kunc et al., 2013). The large-scale retail and shopping centres in Western Europe are going through a stage of remodelling, enlargement and filling in the gaps in the market, and a similar situation is seen in East Central Europe. On the contrary, a noticeable expansion in this respect can be seen in Russia and Turkey, provided they are perceived as marginal European markets (Geo marketing, GfK, 2017).

The strongest retail segment is usually food, which was recently dislodged from the city centres of Central and Eastern Europe (similarly to what happened earlier in Western Europe), but is now returning in a specialised form (Mulíček and Osman, 2013; Syrovátková et al., 2015). Despite the fact that many consumers still prefer quantity, experts speak about the efficiency of shopping and consumption. The 'impulse buying' supported by advertising, promotional events, and the so-called POS (point of sale) / POP (point of purchase) market tools, is decreasing as people tend to think twice about what they want to buy and why. A second significant tendency is the focus on quality and value, which is now typical not only for the Western consumer. Daily shopping for fresh food and an increase in the purchase of branded and cheaper goods in sales, are proof of such a tendency (e.g. Dunne et al., 2011; Križan et al., 2015).

It is obvious from the previous Table 2 that the Eastern markets still have a certain potential regarding the selling areas. Some of the Western chains have made use of this by developing their own chains (e.g. Auchan, Carrefour, Delhaize Group or Agrokor Group).

Another new trend is the opening of so-called premium formats and introducing new concepts that offer to consumers a better selling culture, along with more comfortable shopping and better service (typically the discount store Lidl, partially also Kaufland). Besides the well-established markets of Central Europe, an extensive Polish market has primarily become attractive for Western retailers, together with the south-eastern part of Europe, such as Romania, Bulgaria, Slovenia and Croatia. (Geomarketing, GfK, 2017; RegioData Research, 2017).

The above-mentioned trend for an uninterrupted retail decrease in the share of expenses of consumers in the developed European markets continued into 2016. Europeans tend to invest more of their disposable income in health care, medicine and gastronomy, as well as in common living costs. The decrease in unemployment and a slight increase in incomes have had a positive effect in many spheres. In 2016, the consumers of EU-28 countries received on average 16,153 EUR per person, which was a $0.7 \%$ (nominally) increase in purchasing power than in the previous year. It is necessary to indicate, however, that disparities in the exchange rates negatively influence the rate of the increase, especially with the devaluation of the British pound. The highest rates of growth were in the countries of Central and Eastern Europe, but they have hardly reached $60 \%$ of the European average (except Slovenia and Estonia) and it is highly improbable that they will equal the more developed countries in the near future see Table 3 (Johnson, 2017; Geomarketing, GfK, 2017; RegioData Research, 2017).

Shopping alliances might boost the Western European markets, or rather save costs and increase price competition (Chatterjee, 2004). Shopping alliance membership has been an important trend in Western Europe in recent years, and such a trend is also moving to the east. The economic future of European retail will be reflected not only in the scheduled withdrawal of some giants from certain markets (e.g. Tesco from Central Europe) but also by making common agreements. More and more chains will operate under the largest European shopping alliance EMD (European Marketing Distribution), which reached an accumulated turnover of 180 billion Euros in 2016, and it will be of little importance anymore which part of Europe they come from and where they operate (Stanciu, 2015; EMD, 2017).

Another successful form of retail cooperation that has been in existence for several decades and is constantly developing and modernising is the franchise. In its modern form, this model moved to Western Europe from the USA in the 1960s (Kacker and Perrigot, 2016). Franchise chains established themselves in convenience stores, while many supermarket or hypermarket chains remained under the ownership of the company. Franchise and systems owned by the firm are probably among the most popular organisational forms of the retail chains in Western Europe,

\begin{tabular}{lllr}
\hline Country & PP $(€)$ & Country & PP $(€)$ \\
\hline Switzerland & 38,965 & Germany & 20,840 \\
Luxembourg & 33,547 & Belgium & 20,447 \\
Norway & 28,255 & Slovenia & 12,115 \\
Iceland & 27,313 & Estonia & 9,853 \\
Great Britain & 23,871 & Slovakia & 9,682 \\
Sweden & 21,431 & Czech Republic & 9,207 \\
Denmark & 21,258 & Poland & 7,583 \\
Austria & 21,095 & Hungary & 6,623 \\
\hline
\end{tabular}

Tab. 3: Selected European countries and their purchasing power per person in 2016 (in €)

Source: RegioData Research (2017) 
as they increase productivity through their influence on the transfer of know-how in the form of intercultural communication and communication adaptation (Ghantous et al., 2018). In comparison, modern forms of the franchise are focused on e-commerce strategies and on-line shopping (Pénard and Perrigot, 2017).

The shift to the Eastern markets was merely a matter of time, and Central and Eastern Europe have become very popular markets for the franchise enterprise of Western European retail chains during the last two decades. Recently, franchise concepts in retail food segments have expanded enormously. This results from the abovementioned fact that even consumers in Eastern Europe have started to turn away from shopping in supermarkets and prefer the smaller and more accessible shops in their neighbourhood (Kunc et al., 2012a). The concept of the franchise is presently perceived as a form of goods and services marketing by a subject that acts as a franchisor and provides more partners - franchisees - with the right to run the retail business using its products or services, under its own name, thereby uniting all the advantages of the direct sale. The franchise is one of the forms through which smalland middle-sized entrepreneurs are able to compete with the large firms. (Doherty, 2009; Križan and Lauko, 2014).

Last but not least, advertising is a major issue in retail marketing, i.e. both the traditional and new trends and forms of communication with the customer, as well as focusing on the chosen communication pathways. According to the German Research Institute EHI Marketingmonitor Handel 2017-2020, investments in digital communications are constantly increasing, yet retailers can hardly do without the standard leaflet. In food retailing, it is the medium with the most significant economic importance and the most advantageous form of offer in terms of communication, and at the same time it has the largest promotional effect. This situation is likely to change in the future, however. The younger target groups, the so-called generation $\mathrm{Z}$, use digital media predominantly, and so the printed advertisement will probably not affect them (Priporas et al., 2017; Fuentes, Svingstedt, 2017). Compared to the costs of printed commercial advertisements, the digital forms not only save on such costs but can be also be directed more precisely to the target group by way of individual personal addressing. According to the above-quoted study, the Internet and smartphones are the first and foremost media for more and more customers when researching retail offers or planning a shopping trip. We should indicate that the advertising and marketing of consumer goods and products are not spatially limited, although certain cultural specifics might be acknowledged. In spite of this, we may observe a significant similarity between Western and Eastern Europe in this sphere of retail.

The newest trends, technological innovations and economic perspectives of the retail sector are regularly presented at the World Retail Congress. Since 2007, world leaders, innovators and retail beginners all meet here. The key topic of the Congress in Madrid in 2018 is "Innovate to Win", and its objective is to increase the efforts in retailing to innovate in all spheres of entrepreneurship, so that the expectations of the current demanding customers are met (World Retail Congress, 2018). The second continuation of the European Retail Conference in Milan in 2018 focuses on the European retail market, and the main topic is the ability to adjust to the changing consumer demands in the fast developing retail sector (RICS, 2018). The twenty- third continuation of the Retail Summit 2018 focuses on the Czech, Slovak and Central European retail markets; organised by the Czech Confederation of Commerce and Tourism and the University of Economics in Prague, it takes place in Prague. Its motto is the search for the balance between the retailer and the customer, the demand trends, and the search for new customers by means of new technologies. The IGD Company, which performs retail analyses, identified five global trends in the retail sector over the next several years on the basis of its global research. They are (after RetailNews 1-2/2018):

1. hybrid concepts of stores;

2. changes in the lifestyles of the consumers;

3. hyper-local retailing;

4. the speed and comfort of shopping; and

5. AI (Artificial Intelligence).

Whether retailing in Eastern and Western Europe has developed differently or similarly, the key question regarding its further progress lies in its planning and constructive regulation. In this context, there is still a significant heterogeneity concerning provisions in the individual countries (Spilková, 2010; England, 2012), so the European Retail Action Plan might be a comprehensive solution (Korthals Althes, 2016).

The economics of the retail sector and retailing is represented by contributions for the distribution and sale of goods (very often in on-line settings), branding, the retailing of professional and consumer services (Alexander and Doherty, 2009; Cristini and Laurini, 2017; Anselmsson et al., 2017; Ertz et al., 2017), retail management, and political and management decision making (Hübner et al., 2016; Gruber et al., 2016; Vyt and Cliquet, 2017). The most significant economic feature of retail research is seen in marketing with its various modifications, such as place marketing, buzzmarketing or geomarketing (Warnaby and Medway, 2004; Teller and Elms, 2012; Kita et al., 2013; Marjanen et al., 2016; Lowe et al., 2018). Another theme in economic research regards the attractiveness of retail environments in the context of municipal retail agglomerations, which are becoming more and more relevant in recent years (Teller and Schnedlitz, 2012; Teller et al., 2016; Križan et al., 2016). In addition, there are analyses of how the shopping centres work (Teller, 2008; Teller and Alexander, 2014; Bilková et al., 2016; Kunc et al., 2016; Gomes and Paula, 2016; Ferreira and Paiva, 2017), and we must not forget the more 'classical' studies focusing on international overviews of the retail sector or transformations in such environments (Nagy, 2001; Burt, 2006; Cliquet, 2006; Simová, 2010; Križan et al., 2016). Retailng, however, is not only the domain of the economists, it is also reflected in the studies of human geographers.

If we focus on the social behaviours of the individual or of population groups, buying behaviour represents one of the basic and most common forms. Buying behaviours can be studied using the perspectives of various social science disciplines - Psychology, Sociology, Anthropology or Human Geography. The psychology of the consumer accounts for the buying behaviour of the individual in relation to their value system, motivations and the realisation of needs, such as for example with respect to the classic Maslow hierarchy of needs or the typology of customers (Maslow, 1943, 1954). Classic studies in this vein include Stone (1954), Lesser, Huges (1986), Guy (1998a), Underhill (1999), Wagner, Rudolph (2010), Dębek (2015), Pyyry (2016) and many 
others. Sociological studies include consumer patterns, buying practices, the social behaviours of a given population or chosen population groups, the influence of the media and advertisements on buying behaviours, etc. These studies have been carried out in different settlement structures (e.g. urban vs. rural localities) or in regional or other subcultures (Schiffman and Kanuk, 2004; Spilková, 2012a; Davies et al., 2017; Križan et al., 2017; Sorensen et al., 2017; Page et al., 2018). In these studies, the psychological and sociological aspects of buying behaviours are very often interconnected, the border being blurred. Geographers, typically working in the area of Behavioural Geography, are often inspired by the methodological approaches of both of these disciplines.

The first geographical studies related to the retail sector are works that are connected to standard location theories, based on the spatial distribution of retailing and services, on distance relations and the hierarchy of settlements and various economic modifications (typically Christaller, 1933/1966; Lösch, 1944/1954). The geography of retailing started to develop as a geographical subdiscipline, according to Križan and Lauko (2014), at the turn of the 1970s and 1980s, although there are also older studies (e.g. Berry, 1967, Očovský, 1973, 1976). At this time it was necessary to create a theoretical-methodological system, the subject and the object of the research, with specialised terminology. In this respect, the following works may be considered groundbreaking: Geography and Retailing (Scott, 1970), Retail Location and Retail Planning (Guy, 1980), or Retail Geography (Dawson, 1981).

In the next two decades (the 1980s and 1990s), geographers, specifically in the Anglo-Saxon world, showed an increased interest in the issues of the retail sector. Some studies emphasised the importance of planning and localisation/locality (Davies and Rogers, 1984; Jones and Simmons, 1987; Guy, 1984, 1994). Some of the first studies, however, started to focus on buying and consumer patterns from the perspective of space and behaviour (Brown, 1992; Marjanen, 1995; Wrigley and Lowe, 1996). Consumption, in the broader sense of the word, perceived as an expression, reproduction and pronouncement of various identities and various forms of economic processes, has become an everyday part of the geographers' work (Ducatel and Blomley, 1990; Mansvelt, 2005). The term "new retail geography" appeared and it enlarged critical discussion in the entire Human Geography community (Lowe and Wrigley, 1996; Crewe, 2000). In the Czech and Slovak geographical communities, empirical studies were devoted mainly to the relations between the retail and settlement systems, or more precisely to their spheres of interest or the developing tendencies of the retail network (Očovský, 1986; Maryáš, 1988; Drtina and Krásný, 1989).

The new millennium has brought new challenges, confrontations and discussions into the geography of retailing. It would not be correct to state that geographers in their studies define the concept of 'Retail Geography' with respect to other scientific disciplines. On the contrary, the borders between the research and published results by geographers, economists, sociologists, psychologists and environmentalists are more and more blurred, which might be considered a logical, and to some extent, even a necessary development in such a multi-disciplinary issue as retailing. In the last two decades, geographers have become more inclined to qualitative (sociological and psychological) research on buying and consumer behaviours, which are frequently perceived as leisure activities in the shopping centre or in the form of visits to a food festival (Spilková, 2003, 2015; Timothy, 2005; Bäckström, 2006, 2011; McEachern and Warnaby, 2006; Mitríková et al., 2015; Timothy and Pena, 2016). Other new studies include those related to the globalisation of retail, economic and medical functions in work on the concept of 'food deserts' or 'healthy food shopping' (Cummins and McIntyre, 2002; Wrigley, 2002; Zenk, 2005; Syrovátková et al., 2015; Križan et al., 2015; Bakos, 2017; Bilková et al., 2017; Wood et al., 2017). Some of the latest trends, such as the 'Internetisation' of retail, on-line shopping or e-commerce and the use of GIS, are emerging in the geographical literature (Clarke et al., 2015; Kita et al., 2018).

This statement on the work of geographers does not imply that they completely abandoned quantitative or qualitative research approaches to retailing and the spatial aspects associated with them - typically regarding the location and planning of the retail structures, shopping catchment areas, the shopping preferences of consumers, work on consumption, etc. (Birkin et al., 2002; Wrigley and Lowe, 2002; Guy, 2007; Mansvelt, 2010; Kunc et al., 2012; Bilková et al., 2015; Birkin et al., 2017). Czech and Slovak geographers also joined these trends, after an absence of approximately ten years (the 1990s), and so they are not falling behind the Anglo-Saxon world anymore (see for example, some comprehensive monographs: Mitríková, 2008; Szczyrba, 2005; Spilková 2012, 2016; Kunc et al., 2013; Križan and Lauko, 2014 or Trembošová et al., 2016).

\section{This Special Issue: "Contemporary retail environments: Shopping behaviour, consumer preferences, retailing and geomarketing"}

The contributions to this Special Issue have a common denominator: retailing - or, perhaps, the consumers. Other key elements are the geographical attitude and perspectives. The texts are not entirely isolated within one research domain, as they partly touch upon the fields of Sociology, Ecology or Management, as well as Geography, all of which are naturally inter-connected in studies of the retail environment.

Most of the contributions report on work on European retail landscapes. Although not explicitly part of any author's mandate, we trust that readers will make some of the inevitable comparisons with the Western European research that we have identified above.

In the first paper, Pedro Guimarães explores the dynamics of shopping centres in Lisbon, with respect to their flexibility and power to liquidate other retail businesses, as well as their weaknesses which can lead to bankruptcy and loss of viability. The resilience of shopping centres to potential failure is thus a crucial aspect of this study. The field research and analyses of the case studies and interviews with managers in the chosen functional centres, deemed as resilient in the context of all shopping centres in Lisbon, contributed to the findings that a wide range of strategic measures may be applied, which are then able to strengthen the importance of the management of the structures in the shopping centres and secure their viability in the present, dynamically developing and changing retail environment. Even though the retail market in Eastern Europe is not yet over-saturated with shopping centres, we may assume that such a situation is about to happen. This excellent contribution proposes some strategic solutions for dealing with such situations. 
Dan-Cristian Dabija, Brînduşa Bejan and David Grant study the impacts of ecological thinking on the loyalty of the consumers in selected regions in Romania in the second paper. The increasing interest of consumers in buying green or sustainable products, their ideas on responsible consumption and on environmental protection and the preservation of resources, form the central elements of the text. Based on extensive field research in three regions (Crişana, Centru and Banat), the authors infer that Romanian retailers win over their customers and their loyalty by adopting strategies based on the principles of sustainability. The results show that awareness of the ecological aspects of consumption is growing among the residents of Eastern Europe, along with their abilities to accept ecological behaviours, in similar ways as previously happened to their Western counterparts.

In our third paper, Jana Spilková proposes in her inquiry about the Czech retail environment, to test a timeless motto: "Tell me where you shop, and I will tell you who you are". Over many many years, consumers in the post-socialist countries had limited chances of shopping and their shopping behaviours could be regarded as relatively "unified". At present, with the arrival of new possibilities for shopping, as shown in this study, there are significant differences between the customers of various retail formats. By analysing an extensive sample of the Czech population (more than 3,000 respondents), the author discovers that there are significant differences between the customers of various retail formats (traditional, large-scale, or alternative outlets), and that such alternative ways of shopping are among the most important factors that characterise Czech customers today. Thus, in Eastern Europe alternative food networks have become an inseparable part of the retail food environment.

The comparison, analysis and interpretation of the shopping behaviours of teenagers and seniors (surveying almost one thousand respondents) in five selected shopping centres in Bratislava (Slovakia) is the aim of the article by František Križan, Kristína Bilková, Josef Kunc, Michaela Sládeková Madajová, Milan Zeman, Pavol Kita and Petr Barlík in the fourth contribution to this Special Issue. The authors focus on the perception of shopping centres by both population groups with respect to time, social and financial aspects. Spatial aspects using the principle of concentric zones are emphasised. In the context of the variables under study in this research, results show that teenagers in Bratislava are not sensitive consumers compared to the seniors. The teenagers perceive the shopping centres as a common part of their consumption, if not their lives; the seniors, to the contrary, perceive the shopping centres less positively and they spend less time there.

For the fifth contribution to this Special Issue, post-soviet European space is represented by a comparative study by Konstantin Axenov, Dovilè Krupickaitè, Kira Morachevskaya and Andrey Zinovyev. Using the examples of Saint Petersburg and Vilnius, they investigate the contrasting developmental stages of "retail expansion" as one of the important processes that re-shaped the former socialist urban environments. The authors employ a comparison of data from the socialist economy of the late 1980s to that of the present time. The last 25 years of the development of the urban environment indicates, on the one hand, a similar or rather an identical path (path dependency) regarding the structural changes of the retail sector, the same as it was with the cities in Western Europe. On the other hand, however, it refers to some of the uniqueness of post-socialist development in urban retail environments.
As an exception to our "European landscapes" orientation, the sixth contribution to this Issue is a study by Sina Hardaker, who highlights the efforts of German discount retail food stores to expand into the largest retail market in the world - the Chinese market. Despite the obvious successes of the German discount stores Aldi and Lidl in recent years (especially as a form of on-line shops), they do not (yet) have any physical (i.e. geographically located) store in the country. Interviews with managers of international retail sellers revealed the main reasons why German (and other) discount concepts did not win any major support in the Chinese market. The companies generally prefer to enter such markets that are highly attractive, with a low market risk and where they can enjoy a competitive advantage, all of which is not quite possible in the Chinese retail market with its consumer preferences.

A broad spectrum of authors from geographically, economically and socio-culturally diverse countries across Europe (and beyond) have presented texts that are highly topical and cover major contemporary key topics concerning (not only) European retailing. They then have uncovered new trends and challenges related not only to the dynamic development of retailing in post-socialist Europe but also in referring to a range of relevant issues related to the increasingly globalised economy:

- changes in the shopping behaviour and shopping habits of the consumers (population groups);

- differences between alternative and traditional types of stores and consumer habits and preferences of the customers;

- influences of ecological thinking (green marketing) on the preferences and loyalty of customers;

- differences and similarities in the development of urban retail structures;

- new strategies for the management of shopping centres guaranteeing viability in the period of economic stagnation; and

- the possibilities and problems related to retail chains entering new markets (China).

We believe that the topics that we have covered in this Special Issue will lead to further popularisation and awareness of research activities on the retail environment, and will hopefully provoke a constructive discussion concerning these dynamically developing interdisciplinary topics.

\section{Acknowledgements}

This paper was elaborated with support from an internal grant of the Faculty of Economics and Administration, Masaryk University, entitled "Cities, municipalities, regions: management, processes and interactions in theory and practice" (MUNI/A/0994/2017), from the Slovak Research and Development Agency under the contract No. APVV-160232, and the project No. 031UK-4/2017

\section{References:}

ALEXANDER, N., DOHERTY, A. (2009): International Retailing. Oxford, Blackwell.

ANSELMSSON, J., BURT, S., TUNCA, B. (2017): An integrated retailer image and brand equity framework: Re-examining, extending, and restructuring retailer brand ekvity. Journal of Retailing and Consumer Services, 38: 194-203. 
BAKOS, I. (2017): Local Food Systems Supported by Communities Nationally and Internationally. Deturope, 9(1): 59-79.

BÄCKSTRÖM, K. (2006): Understanding Recreational Shopping: A New Approach. International Review of Retail, Distribution and Consumer Research 16(2): 143-158.

BÄCKSTRÖM, K. (2011): Shopping as leisure: An exploration of manifoldness and dynamics in consumers shopping experiences. Journal of Retailing and Consumer Services, 18(3): 200-209.

BERRY, B. J. L. (1967): Geography of Market Centres and Retail Distribution. New Jersey, Prentice Hall, Englewood Cliffs.

BILKOVÁ, K., KRIŽAN, F., BARLÍK, P. (2015): Consumers preferences of shopping centers in Bratislava (Slovakia). Human Geographies - Journal of Studies and Research in Human Geography, 10(1): 23-37.

BILKOVÁ, K., KRIŽAN, F., BARLÍK, P. (2016). Consumers preferences of shopping centers in Bratislava (Slovakia). Human Geographies - Journal of Studies and Research in Human Geography, 10(1): 7-21.

BILKOVÁ, K., KRIŽAN, F., BARLÍK, P., HORŇÁK, M., BARLÍK, P., KITA, P. (2017): Comparing two distance measures in the spatial mapping of food deserts: The case of Petržalka, Slovakia. Moravian Geographical Reports, 25(2): 95-103.

BIRKIN, M., CLARKE, G., CLARKE, M. (2017): Retail location planning in an era of multi-channel growth. New York, Routledge.

BROWN, S. (1992): Retail Location: A Micro-scale Perspective. Avebury, Hants.

BURT, S. (2006). Retailing in Eastern Europe - Emerging market within the European Union. In: Zentes, J. [ed.]: Handbuch handel. Strategien - pespektiven internationaler wettbewerb (pp. 111-138). Wiesbaden, Verlag, Springer.

BURT, S. (2010). Retailing in Europe: 20 years on. The International Review of Retail, Distribution and Consumer Research, 20(1): 9-27.

CHATTERJEE, P. (2004): Interfirm alliances in online retailing. Journal of Bussiness Research, 57(7): 714-723.

CHRISTALLER, W. (1933/1966): Central Places in Southern Germany. New Jersey, Prentice Hall.

CLARKE, G., THOMPSON, C., BIRKIN, M. (2015): The emerging geography of e-commerce in British retailing. Regional Studies, Regional Science, 2(1): 371-391.

CLIQUET, G. (2006). Retailing in Western Europe structures and development trends. In: Zentes, J. [ed.]: Handbuch handel. Strategien - pespektiven internationaler wettbewerb (pp. 139-160). Wiesbaden, Verlag, Springer.

COE, N. M., HESS, M. (2005). The internationalization of retailing: implications for supply network restructuring in East Asia and Eastern Europe. Journal of Economic Geography, 5: 449-473.

COLEMAN, P. (2012): Shopping Environments. London, Routledge.

CREWE, L. (2000): Geographies of retailing and consumption. Progress in Human Geography, 24(2): 275-290.
CRISTINI, G., LAURINI, F. (2017): Growth factors of store brands in different store formats in Italy. The International Review of Retail, Distribution and Consumer Research, 27(2): 109-125.

CROSBY, N., HUGHES, C., LIZIERI, C., OUGHTON, M. (2005): A Message from the Oracle: The Land Use Impact of a Major In-town Shopping Centre on Local Retailing. Journal of Property Research 22(2-3): 245-265.

CUMMINS, S., MACINTYRE, S. (2002): A Systematic Study of an Urban Foodscape: The Price and Availability of Food in Greater Glasgow. Urban Studies, 39(11): 2115-2130.

DAVIES, R., ROGERS, D. (1984): Store Location and Store Assessment Research. Chichester, John Wiley \& Sons.

DAVIS, R., SMITH S. D., LANG, B. U. (2O17): A comparison of online and offline gender and goal directed shopping online. Journal of Retailing and Consumer Services, 38: $118-125$.

DAWSON, J. (1981): Retail Geography. London, Croom Helm.

DEBEK, M. (2015): What Drives Shopping Mall Attractiveness? Polish Journal of Applied Psychology, 13(1): 67-118.

DOHERTY, A. M. (2009): Market and partner selection processes in international retail franchising. Journal of Business Research, 62(5): 528-534.

DRTINA, T., KRÁSNÝ, T. (1989): Mezinárodní srovnání vývojových tendencí maloobchodní sítě. Praha, Výzkumný ústav obchodu.

DUCATEL, K., BLOMLEY, N. (1990): Rethinking retail capital. International Journal of Urban and Regional Research, 14(2): 207-227.

DUNNE J. B., CHAMBERS K. J., GIOMBOLINI K. J., SCHLEGEL, S. A. (2011): What does 'local' mean in the grocery store? Multiplicity in food retailers' perspectives on sourcing and marketing local foods. Renewable Agriculture and Food Systems, 26: 46-59.

EMD (2017): European Marketing Distribution [online]. Available at: http://www.emd-ag.com/

ENGLAND, J. (2012). Retail Impact Assessment: A guide to best practice. London, Routledge.

ERTZ, M., DURIF, F., ARCAND, M. (2017): Business at the fingertips of consumers: a scale for measuring resale motivations in online settings. The International Review of Retail, Distribution and Consumer Research, 28(1): 92-114.

FERREIRA, D., PAIVA, D. (2017): The death and life of shopping malls: an empirical investigation on the dead malls in Greater Lisbon. The International Review of Retail, Distribution and Consumer Research, 27(4): 317-333.

FUENTES, C., SVINDGSTEDT, A. (2017): Mobile phones and the practice of shopping: A study of how young adults use smartphones to shop. Journal of Retailing and Consumer Services, 38: 137-146.

GEOMARKETING, GFK (2017). European retail in 2017 [online]. Available at: https://www.across-magazine.com/ european-retail-2017/

GHANTOUS， N., DAS， S. S., CHAMEROY, F. (2018): Governance capabilities and relationship performance in international franchising. Journal of Retailing and Consumer Services, 40: 19-30. 
GOMES, M. R., PAULA, F. (2016): Shopping mall image: systematic review of 40 years of research. The International Review of Retail, Distribution and Consumer Research, 27(1): 1-27.

GRUBER, V., HOLWEG, C., TELLER, C. (2016): 'What a Waste! Exploring the Human Reality of Food Waste from the Store Manager's Perspective'. Journal of Public Policy and Marketing, 35(1): 3-25.

GUY, C. (1995): The Retail Development Process: Location, Property and Planning. London, Routledge.

GUY, C. M. (1998): Classifications of retail stores and shopping centres: some methodological issues. GeoJournal, 45(4): 255-264.

GUY, C. M. (1980): Retail Location and Retail Planning. Farnborough, Gower

GUY, C. M. (1984): The urban pattern of retailing (Within the UK). In: Davies, R., Rogers, D. [eds.]: Store Location and Store Assessment Research. New York, John Wiley \& Sons: 73-90.

GUY, C. M. (1994): The Retail Development Process: Location, Property and Planning. London, Routledge.

GUY, C. M. (2007): Planning for Retail Development: A Critical View of the British Experience. New York, Routledge.

HÜBNER, A., HOLZAPFEL, A., KUHN, H. (2016): Distribution systems in omni-channel retailing. Business Research, 9(2): 255-296.

JOHNSON, I. (2017). A crisis in the European order? Orbis, 61(2): 286-290.

JONES, K., SIMMONS, J. (1987): Location, Location, Location. London, Methuen.

KACKER, M., PERRIGOT, R. (2016): Retailer use of a professional social media network: Insights from franchising. Journal of Retailing and Consumer Services, 30: 222-233

KEARNEY, A. T. (1995). Top 30 Most Attractive Emerging Marketsfor International Retailers. The 1996 Globalretail Development Index [online]. Available at: http://www. atkearney.in/documents/10192/577444/GRDI_1996.pdf/ b9a84a5f-db28-47d3-be18-499128528397

KITA, P., KITA, J., KONŠTIAK, P., KRIŽAN, F., HASAN, J., REIFF, M. (2013): Geografický informačný systém inovatívny nástroj posilňovania konkurencieschopnosti maloobchodných podnikov. Bratislava, EKONÓM

KITA, P., SZCZYRBA, Z., FIEDOR, D., LÉTAL, A. (2018): Recognition of business risks when purchasing goods on the Internet using GIS: experience from Slovakia. Electronic Commerce Research 18(3): 647-663.

KOK, H. J. (2007). Restructuring retail property markets in Central Europe: Impacts on urban space. Journal of Housing and the Built Environment 22: 107-126.

KORTHALS ALTES, W. K. (2016): Freedom of establishment versus retail planning: The European case. European Planning Studies, 24(1): 163-180.

KRIŽAN, F., BILKOVÁ, K., KITA, P. (2014): Urban retail market in Bratislava (Slovakia): Consumers perception and classification of shopping centres. Management \& Marketing. Challenges for the Knowledge Society, 9(4): 483-500
KRIŽAN, F., BILKOVÁ, K., KITA, P., HORŇÁK, M. (2015): Potential food deserts and food oases in a post-communist city: Access, quality, variability and price of food in Bratislava-Petržalka. Applied Geography, 62(8): 8-18.

KRIŽAN, F., BILKOVÁ, K., KITA, P., SIVÍČEK, T. (2016): Transformation of retailing in post-communist Slovakia in the context of globalization. E + M. Ekonomie a management, 19(1): 148-164.

KRIŽAN, F., LAUKO, V. (2014): Geografia maloobchodu. Uvod do problematiky. Bratislava, UK Bratislava.

KRIŽAN, F., PAŠKO, M., BILKOVÁ, K., BARLÍK, P., KITA, P. (2016): Heterogeneity of shopping centers' attractiveness in Bratislava. Geographia Technica, 11(2): 61-68.

KRIŽAN, F., ZEMAN, M., BILKOVÁ, K., KITA, P., BARLÍK, P. (2017): Crossborder shopping behaviour of consumers from Slovakia: case study from Hainburg an der Donau (Austria). Geographia Cassoviensis, 11(2): 124-136.

KUNC, J. et al. [eds.] (2013): Časoprostorové modely nákupního chování české populace. Brno, Munipress.

KUNC, J., FRANTÁL, B., TONEV, P., SZCZYRBA, Z. (2012a): Spatial Patterns of Daily and Non-daily Commuting for Retail Shopping: Case of the Brno City, Czech Republic. Moravian Geographical Reports 20(4): 39-54.

KUNC, J., TONEV, P., FRANTÁL, B., SZCZYRBA, Z. (2012b): Nákupní spád, nákupní chování a nákupní centra: příklad brněnské aglomerace (přispěvek ke studiu denních urbánních systémů). Sociologický časopis 48 (5): 879-910.

LESSER, J. A., HUGES, M. A. (1986): Towards a typology of shoppers. Business Horizons, 29(6): 56-62.

LÖSCH, A. (1944/1954): The Economics and Location. New Haven, Yale University Press.

LOWE, J., MAGGIONI, I., SANDS, S. (2018): Critical success factors of temporary retail activations: A multi-actor perspective. Journal of Retailing and Consumer Services, 40: $74-81$.

LOWE, M., WRIGLEY, N. (1996): Towards the new retail geography. In: Wrigley, N., Lowe, M. [eds.]: Retailing, Consumption and Capital. London, Longman: 3-30.

MACHEK, M. (2012). Retail market structure development in Central Europe. Central European Business Review, 1(3): 22-27.

MANSVELT, J. (2005): Geographies of Consumption. London, Sage.

MANSVELT, J. (2010): Geographies of consumption: Engaging with absent presences. Progress in Human Geography, 34(2): 224-233.

MARJANEN, H. (1995): Longitudinal Study on Consumer Spatial Shopping Behaviour with Special Reference to Out-of Town. Experiences from Turku, Finland. Journal of Retailing and Consumer Services 2(3): 163-174.

MARJANEN, H., KOHIJOKI, A-M., SAASTAMOINEN, K. (2016): Profiling the ageing wellness consumers in the retailing context. The International Review of Retail, Distribution and Consumer Research, 26(5): 477-501.

MARYÁŠ, J. (1988): Nadmístní střediska maloobchodu a služeb v ČSSR a jejich sféry vlivu. [Kandidátská disertační práce]. Brno, Geografický ústav ČSAV.

MASLOW, A. H. (1943): A Theory of Human Motivation. Psychological Review, 50(4): 370-96. 
MASLOW, A. H. (1954): Motivation and personality. New York, Harper and Row.

MCEACHERN, M. G., WARNABY, G. (2006): Food Shopping Behaviour in Scotland: The Influence of Relative Rurality. International Journal of Consumer Studies, 30(2): 198-201.

MITRÍKOVÁ, J. (2008): Geografické aspekty transformácie maloobchodu a nákupného správania sa na Slovensku (prípadové štúdie z miest Prešov a Košice). Prešov, Prešovská univerzita.

MITRÍKOVÁ, J., ŠENKOVÁ, A., ANTOLIKOVÁ, S. (2015): Application of the Huff Model of Shopping Probability in the Selected Stores in Prešov (Prešov, the Slovak Republic). Geographica Pannonica, 19(3): 110-121.

MULÍČEK, O., OSMAN, R. (2013): Průzkum maloobchodní sítě na území města Brna 2013. Brno, Masarykova univerzita.

MYERS, H., ALEXANDER, N. (1997): Food Retailing Opportunities in Eastern Europe. European Business Review, 97(3): 124-133.

NAGY, E. (2001). Winners and losers of the transition of city centre retailing in east Central Europe. European Urban and Regional Studies 8: 340-349.

OČOVSKÝ, Š. (1973): Príspevok k štúdiu spádových území obchodných stredísk na Slovensku. Geografický časopis, 25(1): 122-135.

OČOVSKÝ, Š. (1973): Vybrané problémy štúdia nákupných miest. Geografický časopis, 28(1): 23-36.

OČOVSKÝ, Š. (1986): Vztah maloobchodu a sídelného systému na Východoslovenskej nížine. Geografický časopis, 38(1): 43-59.

PANTANO, E. (2010). New technologies and retailing. Trends and directions. Journal of Retailing and Consumer Services, 17: 171-172.

PÉNARD, T., PERRIGOT, R. (2017): Online search - Online purchase in franchising: An empirical analysis of franchisor website functionality. Journal of Retailing and Consumer Services, 39: 164-172.

POSPĚCH, P. (2015): Od veřejného prostoru k nákupním centrům: Svět cizinců a jeho regulace. Praha, Slon.

PRIPORAS, C-V., STYLOS, N., FOTIADIS, A. K. (2017): Generation Z consumers' expectations of interactions in smart retailing: A future agenda. Computers in Human Behavior, 77: 374-381.

PYYRY, N. (2016): Participation by being: Teenage girls hanging out at the Shopping Mall as 'dwelling with' [the World]. Emotion, Space and Society, 18: 9-16.

REGIODATA research (2017): Regional economic data for Europe [online]. Available at: http://www.regiodata.eu/en/

RetailNews (2017): EHI-marketingmonitor Handel 2017-2020 [online]. Available at: http://archiv.press21. cz/retailnews/2017/11/ and https://www.ehi.org/de/ studien/marketingmonitor-handel-2017-2020/

RetailNews (2018): Sílí prolínání internetových a klasických obchodů [online]. Available at: http://archiv.press21.cz/ retailnews/2018/1-2

RICS European Retail Conference (2018): [online] Available at: http://www.rics.org/cz/training--events/conferencesseminars/rics-european-retail-conference/milano-/
SCOTT, P. (1970): Geography and Retailing. London, Hutchinson.

SCHIFFMAN, L. G., KANUK, L. L. (2004). Nákupní chování. Brno, Computer Press.

SIMOVÁ, J. (2010). Internationalization in the process of the Czech retail development. E + M. Economics and management, 2: 78-91.

SORENSEN, H., BOGOMOLOVA, S., ANDERSON, K., TRINH, G., SHARP, A., KENNEDY, R., PAGE, B., SPILKOVÁ, J. (2015): Leisure time preferences and health risk behavior of teenagers in the post-communist Central European countries. Childrens' geographies, 13(4): 435-450

SPILKOVÁ, J. (2010). Retail Development and Impact Assessment in Czech Republic: Which Tools to Use?. European Planning Studies, 18(9): 1469-1484.

SPILKOVÁ, J. (2012a): The Birth of the Czech Mall Enthusiast: The Transition of Shopping Habbits from Utilitarian to Leisure Shopping. Geografie, 117(1): 21-32.

SPILKOVÁ, J. (2012b): Geografie maloobchodu a spotřeby. Praha, Karolinum.

SPILKOVÁ, J. et al. (2016): Alternativní potravinové sítě: Česká cesta. Praha, Karolinum.

STANCIU, S. (2015): The Romanian Retail Food Market Survival or Success for Domestic Companies. Procedia Economics and Finance, 23: 1584-1589.

STARZYCZNÁ, H. (2010): Vybrané aspekty internacionalizace vnitřního obchodu $\mathrm{v}$ teoretických přístupech a v empirickém zkoumání v České republice v období transformace. E + M. Ekonomie a management, 1: $115-130$.

STONE, G. (1954): City shoppers and urban identification: observation on the social psychology of city life. American Journal of Sociology, 60: 35-54.

SYROVÁTKOVÁ, M., HRABÁK, J., SPILKOVÁ, J. (2015): Farmers' markets' locavore challenge: The potential of local food production for newly emerged farmers' markets in Czechia. Renewable Agriculture and Food Systems, 30(4): 305-317.

SZCZYRBA, Z. (2005): Maloobchod v ČR po roce 1989 vývoj a trendy se zaměřením na geografickou organizaci. Olomouc, Univerzita Palackého.

SZCZYRBA, Z. (2010): Development of retail geographical structure in the Czech Republic. A contribution to the study of urban environment changes. AUPO Gegraphica, 41(2): 5-20.

TELLER, C. (2008): Shopping streets versus shopping mallsdeterminants of agglomeration format attractiveness from the consumers' point of view. The International Review of Retail, Distribution and Consumer Research, 18(4): 381-403.

TELLER, C., ALEXANDER, A. (2014): Store managers-the seismographs in shopping centres. European Journal of Marketing, 48(11/12): 2127-2152.

TELLER, C., ELMS, J. R. (2012): Urban place marketing and retail agglomeration customers. Journal of Marketing Management, 28(5-6): 546-567.

TELLER, C., SCHNEDLITZ, P. (2012): Drivers of agglomeration effects in retailing: The shopping mall 
tenant's perspective. Journal of Marketing Management, 28(9-10): 1043-1061.

TELLER, C., ALEXANDER, A., FLOH, A. (2016): The impact of competition and cooperation on the performance of a retail agglomeration and its stores. Industrial Marketing Management, 52: 6-17.

TIMOTHY, D. J. (2005): Shopping Tourism, Retailing, and Leisure. New York, Channel View Publications.

TIMOTHY, D. J., PENA. M. (2016): Food festivals and heritage awareness. In: Timothy, D. J. [ed.]: Heritage Cuisines: Traditions, Identities and Tourism (pp. 149165). New York, Routledge.

TREMBOŠOVÁ, M., DUBCOVÁ, A., KRAMÁREKOVÁ, H., NAGYOVÁ, L'. (2016): Nákupné správanie obyvatelstva města Nitry. Nitra, Slovenská pol’nohospodárska univerzita v Nitre.

UNDERHILL, P. (1999): Why We Buy. The Science of Shopping. New York, Simon \& Schuster.

VYT, D., CLIQUET, G. (2017): Towards a fairer manager performance measure: a DEA application in the retail industry. The International Review of Retail, Distribution and Consumer Research, 27(5): 450-467.

WAGNER, T., RUDOLPH, T. (2010): Towards a Hierarchical Theory of Shopping Motivation. Journal of Retailing and Consumer Services 17(5): 415-429.
WARNABY, G., MEDWAY, D. (2004): The Role of Place Marketing as a Competitive Response by Town Centres to Out-of-town Retail Developments. The International Review of Retail, Distribution and Consumer Research, 14(4): 457-477.

WOOD, S., WRIGLEY, N., COE, N. M. (2017): Capital discipline and financial market relations in retail globalization: Insights from the case of Tesco plc. Journal of Economic Geography, 17(1): 31-57.

World retail Congress (2018) [online]. Available at: https:// www.worldretailcongress.com/

WRIGHT, M. (2017): Fundamental patterns of in-store shopper behavior. Journal of Retailing and Consumer Services, 37: 182-194.

WRIGLEY, N., LOWE, M. (2002): Reading Retail: A Geographical Perspective on Retailing and Consumption Spaces. London, Arnold.

WRIGLEY, N., LOWE, M. [eds.] (1996): Retailing, Consumption and Capital. London, Longman.

ZENK, S. N., SCHULZ, A. J., IZRAEL, B. A., JAMES, S. A., BAO, S., WILSON, M. L. (2005): Neighborhood Racial Composition, Neighborhood Poverty, and the Spatial Accessibilty of Supermarkets in Metropolitan Detroit. American Journal of Public Health, (95)4: 660-667.

\section{Please cite this article as:}

KUNC, J., KRIŽAN, F. (2018): Changing European retail landscapes: New trends and challenges. Moravian Geographical Reports, 26(3): 150-159. Doi: 10.2478/mgr-2018-0012. 